\title{
A főszerkesztő előszava
}

Folyóiratunk huszonharmadik számát tartja kezében a tisztelt Olvasó. Ezúttal tíz szöveget közlünk, amelyek témájukat tekintve szorosan kapcsolódnak egymáshoz. A környezeti (környezetvédelmi) felelösség problémakörét járjuk körül, különböző jogi, köz-, illetve szakpolitikai megközelítések alkalmazásával. Első tematikus, sajátos szempont szerint szerkesztett lapszámunk ez, amelynek megszületésében vendégszerkesztő is közreműködött. A lapszám egyúttal az alapvető jogok biztosa jövő nemzedékek érdekeinek védelmét ellátó biztoshelyettesével, azaz a jövő nemzedékek szószólójával való együttmüködésünk eredménye.

A környezeti felelősség mint tudományos kutatási tárgy időszerüségét a lapszámban közölt írások egytől egyig igazolják. Számos olyan esetre támaszkodnak, amelyekben a társadalom széles köre is szembesülhetett egy-egy szennyezés bekövetkeztével, majd a megnyugtató, teljes körủ megoldások elmaradásával. Szennyezett területeink, telephelyeink száma a térség más országaival összevetve is - bár a hasonló gazdaságtörténeti előzmények alapján talán nem erre számítanánk - kiemelkedően magas. Az ebböl fakadó területhasználati konfliktusok, környezet-egészségügyi problémák, a szennyeződések tovaterjedésével járó, további veszélyek, a jövőbeli környezeti károknak a klímaváltozás miatt is fokozódó kockázatai miatt a felelősség mint környezetpolitikai szabályozóeszköz szerepe felértékelődik. Súlyos környezeti katasztrófák árnyékában a társadalom igazságérzete a büntetőjogi felelősség erősítése irányában is hathat (mint történt például a 2010-es vörösiszapkatasztrófa utóéletében), miközben a kevésbé látványos, de esetleg egészségünkre, életfeltételeinkre hosszabb távon veszélyt jelentő problémákkal hajlamosak vagyunk megbékélni. Ez aláhúzza a vállalatok társadalmi felelősségvállalásának és az állam tudatos, arányos jelenlétének a szükségességét is.

A környezetvédelmi felelösség szerepe (gyakorlati jelentősége) jellemzi a mindenkori környezetpolitikát, illetve közvetve az adott társadalom környezethez való viszonyát. A környezetpolitika súlya és prioritásai pedig időről időre változnak, amely hangsúlyeltolódások szintén nyomon követhetök tanulmányainkban.

A környezeti felelősség sokkal összetettebb a jogi felelősség klasszikus jogági felelősségi konstrukcióinál. Már maga a felelősség kifejezés is - jogi szakkifejezésként - többféle értelemben használatos, és a környezetvédelmi jogi felelősség érvényesítése is számos - különböző jogágakhoz sorolható - jogintézmény, szabályozóeszköz együttes alkalmazásával lehetséges. E komplexitás ráadásul csak egyre növekszik, ahogyan a tudományos ismeretek gyarapodnak, és ahogyan a környezeti problémákat a jogi szabályozás egyre inkább törekszik rendszerbe ágyazva, 
folyamatokként - s nem csak a gazdasági-társadalmi folyamatok szakpolitikai szempontól, mesterségesen szeparált részeiként - megragadni.

E folyamatok korántsem rajzolnak ki egyenes ívet. A gazdaságot megrengető 2008-as válság, vagy a 2020-as pandémia egyaránt változásokat hozott a gazdaságpolitika és a környezetpolitika viszonyának a megítélésében. Hangsúlyeltolódások következtek be a környezetinek tekintett szakpolitikai célok sorrendjében is. A klímaváltozásra irányuló intézkedések világszerte ráirányították a figyelmet a gazdasági racionalitások (mint a versenyképesség) és a környezetpolitikai preferenciák szoros kapcsolatára. De a környezetvédelmi szabályozás, azon belül a felelősség érvényesülése összefüggést mutat a társadalmi önszerveződés kérdéskörével, az állam és a civil kezdeményezések egymáshoz való viszonyulásával is, amelyben szintén változások figyelhetök meg.

Hatások és ellenhatások örvényében kell a mindenkor helyes egyensúlyt találni, és esetenként az államnak egy-egy ponton beavatkozni. Ilyen beavatkozási pontként azonosította a jövő nemzedékek szószólója a környezeti felelősség szabályozásának, gyakorlatának finomhangolását, s ezért állított össze és tett közzé 2019-ben jogalkotási kezdeményezést.

E lapszámunk szerzői közt egyaránt szerepelnek a jogalkotási kezdeményezés elkészítésében részt vevő szakemberek, az előzetes szakmai egyeztetések és konferenciák résztvevői, előadói, illetve egy-egy fontos megközelítés kidolgozására általunk felkért kutatók. Magát a kezdeményezést Bándi Gyula mutatja be „belülröl”, a környezetvédelmi felelősség fogalmának tág értelmezését véve alapul. A környezeti felelősségi szabályaink meghatározott köre európai uniós háttérrel rendelkezik, amelynek hazai, tagállami érvényesüléséröl Kecskés Gábor tanulmányát olvashatjuk. A felelősséget mint környezetpolitikai szabályozóeszközt szabályozás-módszertani (részben környezet-gazdaságtani) megközelítésben Fodor László tárgyalja. Sulyok Katalin a természettudományok bizonytalanságai és a jogi döntésekkel szemben érvényesülő elvárások közti feszültséget tárja elénk. Fülöp Sándor a környezetvédelmi társadalmi szervezetek nemzetközi hálózatának gyakorlati tapasztalatait hasznosítva ad értékelést. Pánovics Attila a civil szervezetek részvételi lehetőségeit a nemzetközi és Európa-jogi elvárások, valamint a hazai szervezetek helyzetének tükrében vizsgálja. Bartha lldikó, Bordás Péter és Horváth M. Tamás a környezetpolitika árnyoldalának, a gazdasági és a környezeti megfontolások viszonyának megvilágításával ad távolabbi perspektívát a környezeti felelősség problémakörének. Agócs Ilona az állami felelösség kérdéskörét a hátrahagyott szennyezések példáján keresztül foglalja történeti és alkotmányjogi keretbe. Gyulai-Schmidt Andrea az állami felelősségi körbe tartozó környezetvédelmi feladatok ellátásának közbeszerzési jogi kérdéseit teszi fel, nemzetközi példákat hozva fel a válaszadáshoz. A sort vendégszerkesztőnk, Pump Judit összegző, s a tanulmányokban nem vizsgált, további szempontokat is felvillantó tanulmánya zárja.

Jóllehet, tanulmányaink egy része jelentős mértékben támaszkodik rá, folyóiratunk elektronikus változatában nem tartjuk szükségesnek közölni a környezeti felelősség hatékonyabb érvényesítése érdekében született, biztoshelyettesi jogalkotási kezdeményezést, amely elérhető a https://www.ajbh.hu/documents/10180/3157803/ Jogalkotási_kezdeményezés_környezeti_felelősség/4821a1da-bb6b-8659-e97f$66 f 8 b 679 c 17 d$ címen. 
Lapszámunkhoz ezúttal a környezetvédelem egyik úttörője, Rachel Louise Carson (1907-1964) mára már klasszikussá vált gondolatát választottuk mottóként: „But man is a part of nature, and his war against nature is inevitably a war against himself." (Az ember azonban a természet része, így a természet elleni háborúja szükségképpen háború önmaga ellen.)

Debrecen, 2020 őszén

a szerkesztőség nevében:

Fodor László 